Wojciech Rogóż ${ }^{1}$ (1), Karolina Kulig ${ }^{1}$, Magdalena Knopik-Koclęga², Agnieszka Szkudlarek ${ }^{1}$, Małgorzata Maciążek-Jurczyk ${ }^{1}$ (1)

${ }^{1}$ Department of Physical Pharmacy, Faculty of Pharmaceutical Sciences in Sosnowiec, Medical University of Silesia, Katowice, Poland

${ }^{2}$ Apteka Zdrowit, Piekary Śląskie, Poland

\title{
Analysis of antibiotic resistance genetic conditioning of Enterobacteriaceae NDM-1 family members and the related epidemiological threat in Poland
}

\author{
Corresponding author: \\ Wojciech Rogóż, Department \\ of Physical Pharmacy, Faculty \\ of Pharmaceutical Sciences \\ in Sosnowiec, Medical University \\ of Silesia, Katowice, Poland \\ e-mail:wrogoz@sum.edu.pl
}

Medical Research Journal 2019; Volume 4, Number 4, 216-224 10.5603/MRJ.a2019.0039 Copyright (C) 2019 Via Medica ISSN 2451-2591

\begin{abstract}
Antibiotic resistance is an extremely serious threat to the modern world. Since 2008, Gram-negative rods from the Enterobacteriaceae family gained the possibility of $\beta$-lactam degradation using NDM-1 carbapenemase, encoded by the blaNDM gene. It often occurs in the genome of Klebsiella pneumoniae and can occur on both bacterial chromosome and plasmids. This creates a very high risk due to the widespread occurrence of bacteria from this family both in the environment and in human microflora. Lack of sensitivity to popular $\beta$-lactam antibiotics is especially dangerous for patients hospitalised for a long time with reduced immunity. In Poland, since 2011, the number of registered NDM+ isolates and related infections are constantly increasing, reaching 1780 cases in 2016 . Bacilli showing the presence of the blaNDM gene are registered very often in the Mazowieckie and Podlaskie regions, while the number of such cases is the lowest in the Opolskie region. Inhibiting the growing number of infections caused by Enterobacteriaceae NDM + is extremely difficult, and one of the methods to reduce this phenomenon is strict compliance with hygiene rules.
\end{abstract}

Key words: NDM-1, antibiotic resistance, Enterobacteriaceae

Med Res J 2019; 4 (4): 216-224

\section{Introduction}

The phenomenon of antibiotic resistance is one of the biggest threats for public health in the modern world. It is a problem not only for the inhabitants of countries where hygiene rules are not respected, or for people with reduced immunity who have been hospitalised for a long time, but also for all those who may potentially have contact with bacteria that is insensitive to antibiotics. A particularly dangerous example of such a microorganism is Klebsiella pneumoniae "New Delhi", which produces metallo- $\beta$-lactamase rod from the Enterobacteriaceae family, the frequency of occurrence of which is constantly increasing in Poland and throughout the world.

\section{Enterobacteriaceae family}

The family of Gram-negative Enterobacteriace$a e$ is an extremely diverse and very broad group of bacteria. They belong to the most common microorganisms in nature such as: Enterobacter, Klebsiella, Escherichia, Shigella, Salmonella, Yersinia, Proteus, or Serratia. They include hundreds of species that live in water, soil, plants, and animals and are an extremely important element of human microflora. Most of them are not dangerous to people. Individual species, such as Yersinia pestis, are always pathogenic to humans, while others may cause opportunistic infections (e.g. Proteus mirabilis). The majority of bacilli belonging to this family, especially opportunistic, can move by cilia and are relative anaerobes. All of the Enterobacteriaceae members have the following common features: the ability to ferment glucose and reduce nitrates, and a lack of cytochrome oxidase and catalase production. An extremely important species of the rod that belongs to the mentioned family was discovered in the $19^{\text {th }}$ century: Klebsiella pneumoniae. It is an element of the natural human microflora [1,2]. It occurs in the oropharynx and rectum of people who are its carriers 
[3, 4]. Klebsiella pneumoniae exists under anaerobic conditions, has the ability to ferment glucose and fructose, and on the MacConkey medium it grows in the form of a highly characteristic colonies, slightly pink, sometimes milky pink, reminiscent of morning dew drops, often with round, smooth shapes. Due to the very thick, mucous envelope, $K$. pneumoniae colonies have a slippery, moist surface [1, 2]. This envelope is also an important feature of virulence [1]. Bacteria from this species produce urease, enabling the breakdown of urea into ammonia, which facilitates the colonisation of the infected organism by limiting the function of the immune system. K. pneumoniae is an extremely important aetiological factor in hospital infections. People treated with long-term antibiotic therapy are particularly vulnerable to colonisation with this pathogen. Unfortunately, $K$. pneumoniae is acquiring resistance to new, commonly used groups of antibiotics and chemotherapeutics, which is a growing problem [3].

\section{The phenomenon of antibiotic resistance}

There are many definitions of antibiotic resistance as well as forms, causes, and consequences of this phenomenon. The simplest of them says that it is a condition in which bacteria are not sensitive to the effects of an antibiotic, and it is caused by certain specific features of bacterium [2, 4, 5]. Incorrect behaviour of patients, doctors, farmers, cattlemen, and food industry employees, resulting from ignorance or disregard of current recommendations, have contributed to the rapid increase in the importance of bacteria defence mechanisms against antibiotics. Antibiotic resistance of bacteria can be natural when insensitivity to a given antibiotic or a whole group is a constant characteristic for a species, e.g. due to the lack of a structure on which the antibiotic can act, or acquired nature, when the gene structures determining drug resistance are introduced into bacterial cells together with DNA by conjugation, transduction, or transformation [2, 4, 5]. The reservoir of genes determining antibiotic resistance are not only pathogenic bacteria, but also those harmless to humans, commonly found in the environment [5]. Bacteria showing resistance to antibiotics realise this feature using various mechanisms that neutralise the drug, e.g. prevention of drug penetration into the cell due to a thick cell wall, enzymatic degradation of the antibiotic, or its modification by adding new functional groups to its molecule, overproduction of the factor being an antibiotic placeholder, active removal of the drug with other toxins using efflux pumps, or such a change in metabolic pathways in the cell to replace that one on which the antibiotic acts $[4,5]$.

\section{$\beta$-lactam antibiotics}

$\beta$-lactam antibiotics are the most important and commonly used group of antimicrobial drugs. The key element of their structure, characteristic for all representatives of this group of drugs, is the presence in their molecule of a four-element $\beta$-lactam ring, which determines their biological function. They show bactericidal activity by the inhibition of the synthesis of peptidoglycan, which is an element that builds the cell wall in bacterial cells. This is possible due to the interaction with penicillin-binding protein (PBP) involved in the final stage of cross-linking murein subunits in a process called transpeptidation. They are bactericidal against many Gram-positive bacteria, as well as some of the Gram-negative bacteria, including those belonging to the Enterobacteriaceae family. This is possible due to the activation of autolysis, disruption of the ion balance of Gram-negative bacteria, as well as stimulation of holin formation. There are five main groups of $\beta$-lactam antibiotics: penicillins, cephalosporins, cephamycins, carbapenems, and monobactams. Unfortunately, many mechanisms of resistance to $\beta$-lactams are known. These include the production by bacteria of enzymes that hydrolyse the binding in the $\beta$-lactam ring and thereby inactivation an antibiotic molecule, mutations within the PBP protein sequence - leading to changes in its structure, the formation of a completely new form of the PBP protein, not showing affinity for $\beta$-lactam antibiotics, and disruption of the transport (specific for Gram-negative bacteria) to the cell of the antibiotic by changing the amount and structure of porin proteins and the active removal of the drug from the bacterial cell $[1,6,7]$.

\section{Enzymatic degradation of antibiotics}

Enzymatic degradation of the antibiotic, especially $\beta$-lactams (the basis of their construction is a $\beta$-lactam ring), is a very common defence mechanism for bacteria. They have a characteristic enzyme that is necessary to exhibit biological activity, involving the inhibition of the synthesis of Gram-positive bacteria cell wall. A very large group of enzymes that inactivate $\beta$-lactam antibiotics are $\beta$-lactamases $[8,9]$. $\beta$-lactamases that show activity towards only one type of antibiotics from this group are named penicillinases, cephalosporinases, or carbapenemases (the names indicate their most important substrates) [7]. Their simplest split by the mode of action includes: serine $\beta$-lactamases (SBL) and metallo- $\beta$-lactamases (MBL). The first of these groups is very large, and belonging enzymes causes the acylation and hydrolysis of the antibiotic using the active centre serine. On the other hand, metallo- $\beta$-lac- 
tamases in the active centre have a zinc cation, which enables $\beta$-lactam ring damage by the interaction with the antibiotic $[8,9,10]$. There are also other $\beta$-lactamase classification systems, e.g. the one proposed by Amber et al. This classification relies on analysis of the evolutionary relationship of enzymes and distinguishing classes A, B, C, and D. Metallo $\beta$-lactamases, such as NDM (New Delhi metallo- $\beta$-lactamase), belong to class $B[11,12]$. Class $A$ includes such carbapenemases as KPC, GES, or MSP. Representatives of classes $C$ and D are CMY and OXA carbapenemases, respectively [13]. Bush and Jacoby are the authors of a classification that assumes the split due to the speed of antibiotic degradation reactions and the potential sensitivity of enzymes to their inhibitors. This split includes groups I, II, III, and IV - metallo- $\beta$-lactamases belong to group III. Their most important common feature is the lack of any sensitivity to inhibitors, as well as high sensitivity to the presence of EDTA that binds metal cations [9, 14, 15]. With the application of $\beta$-lactams that are effective against Gram-negative bacteria, an increase in bacterial infections showing the presence of acquired forms of $\beta$-lactamases has been observed. They are usually encoded on plasmids, and in cells they show constitutive expression [8]. Within class $\mathrm{B}$ of $\beta$-lactamases, several key groups can be distinguished, which are acquired by bacteria. These are: $\beta$-lactamases with extended substrate spectrum, called ESBL, AmpC cephalosporinases, and carbapenemases. The first group provides the bacteria with a resistance to penicillins, cephalosporins, and monobactams, while retaining sensitivity to cephamycins, carbapenems, and $\beta$-lactamase inhibitors. AmpC provides resistance to penicillins, cephalosporins of I-III generation, and monobactams. Carbapenems, considered to be examples of 'last resort' antibiotics, may be degraded by carbapenemases. Class B is their most important class. Its representatives are metallo- $\beta$-lactamases (MBL), which effectively hydrolyse all $\beta$-lactam antibiotics, including carbapenems, with the exception of monobactams [9]. Class $\mathrm{B} \beta$-lactamases contain two zinc cations in the active site - the first cation is associated with three histidines, and the second one with the system of three amino acids: Cys-His-Asp [16]. They are the most active and therefore the most dangerous group of carbapenemases. They were first observed in representatives of the Pseudomonas aeruginosa species in the 1980s, and then in the 1990s in bacteria belonging to the Enterobacteriaceae family. The most important enzymes from the MBL group that a bacterial cell can acquire include IMP, VIM, and NDM [15]. Many groups of researchers are constantly conducting research aimed at obtaining effective NDM-1 metallo- $\beta$-lactamase inhibitors $[17,18]$. Until recently, only inhibitors of serine $\beta$-lactamases, such as clavulanic acid, sulbactam, or tazobactam, which unfortunately showed no activity against MBL, were known. According to the research of Cahill et al., there are compounds that can inhibit both SBL and MBL activity. They are cyclic boroorganic compounds having in their structure a bond between carbon and boron [10]. Another NDM-1 carbapenemase inhibitor is the natural compound isolated from mould, Aspergillomarasmine A (AMA). According to the results from the studies of King et al., it restored bactericidal activity to antibiotics such as meropenem against members of the Enterobacteriaceae family, containing in their genome the bla $\mathrm{NDM}_{\mathrm{ND}}$ gene [19]. There is also a group of compounds that are analogues of penicillins with a free thiol group, called bistiazolidines. They show a high ability to block NDM-1 $\beta$-lactamase activity, leading to inhibition of imipenem hydrolysis by enzymes produced by Escherichia coli NDM+ [20]. Attempts to overcome $\mathrm{NDM}+$ strains using a combination of several currently known and used antibiotics are ongoing. Ojdana et al. showed that the combination of third generation of cephalosporin (ceftazidime), class $\mathrm{A}, \mathrm{B}$, and $\mathrm{D} \beta$-lactamase inhibitor (avibactam) and an organophosphate compound (fosfomycin) shows high efficiency against K. pneumoniae NDM + [21]. Figure 1 shows a simplified classification scheme of acquired $\beta$-lactamases [9].

$K$. pneumoniae can show the presence of many mechanisms of resistance to antibiotics. Data published in 2015 by KORLD from the European network EARSNet, the aim of which was to control antibiotic resistance among bacteria in Europe, comprising several hundred tested isolates from about 60 hospitals, show that $100 \%$ of $K$. pneumoniae in Poland are resistant to aminopenicillins. From the reported data, it follows that more than $60 \%$ of the bacilli from this species are insensitive to fluoroquinolones and third-generation cephalosporins, and more than half to aminoglycosides. A very large proportion of the isolates turned out to be resistant to all three groups of drugs. Only $0.3 \%$ of all isolates showed resistance to carbapenemases [22].

\section{Genesis K. pneumoniae NDM-1}

In 2008 the first person in the world to be diagnosed with infection of a bacteria strain (now called K. pneumoniae NDM-1) was a Swede of Indian origin. He was diagnosed in a hospital in New Delhi with a urinary tract infection. Bacteria isolated from his urine proved to be extremely resistant to ampicillin, cefoxitin, cefuroxime, ceftazidime, and piperacillin. They were sensitive only to colistin and tigecycline [23]. One of the reasons for the appearance of this form of antibiotic resistant bacteria was insufficient compliance in South Asia with the rules of hygiene and environmental pollution. Bacteria showing the presence of NDM-1 carbapenemase also very 


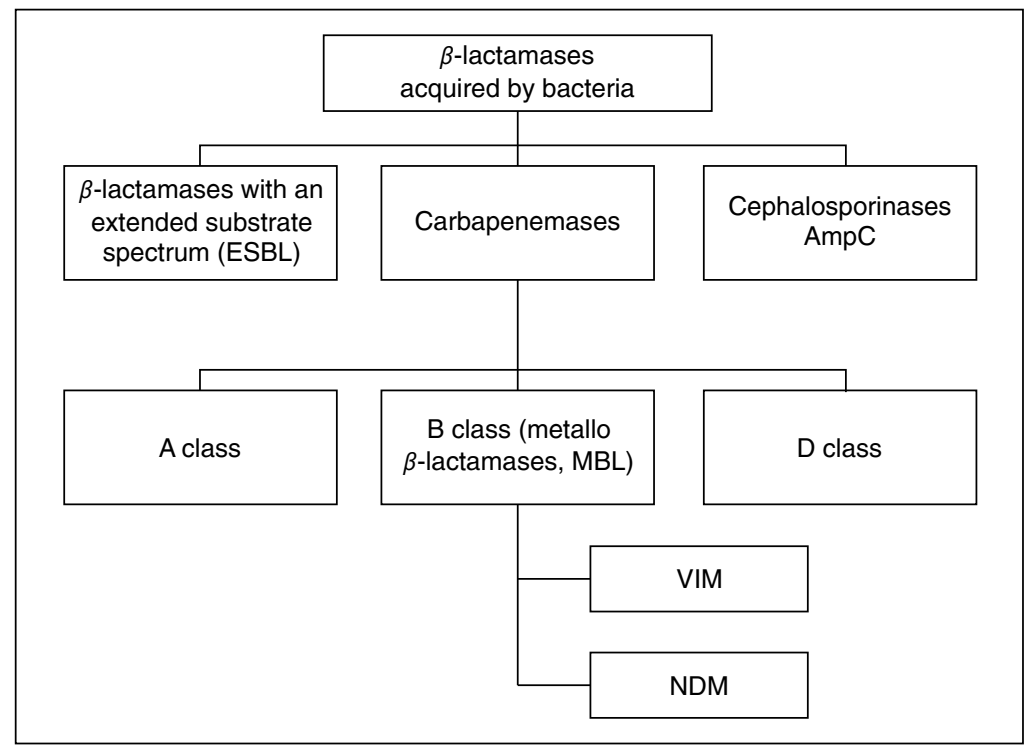

Figure 1. A simplified classification scheme of acquired $\beta$-lactamases [9]

often belong to the species $E$. coli and Enterobacter cloacae $[24,25]$. A high risk of infection with bacteria showing the ability to produce NDM-1 occurs in India and other regions of southern Asia [26]. The list of countries where the risk of infection is high, apart from such Asian countries as China or Japan, includes also many European countries, such as: France, Belgium, the Netherlands, Germany, Austria, Sweden, and Norway [27]. A difficult, and sometimes impossible to eradicate, infection with $K$. pneumoniae NDM+ poses a number of threats with available medical devices. One of them is the possibility of infecting kidney transplant recipients, which has been documented by Karczewski et al. [28].

\section{Genetic conditioning of the NDM resistance mechanism}

The bla NDM $_{\text {gene is }}$ responsible for coding the NDM-1 enzyme [29]. It can be located both on the bacterial chromosome and on plasmids [27]. The second of these locations promotes horizontal gene transfer and the spread between bacteria of the gene encoding the carbapenemase $[27,29]$. The bla $\mathrm{NDM}_{\mathrm{N}}$ gene has been located on plasmid types such as IncF [30, 31], IncA/C [30, 32], or IncL/M [33]. Particularly dangerous are cases are those in which, apart from the bla NDM $_{1}$ gene, other genes that determine antibiotic resistance are also found on the plasmid. The results of this type of analysis were presented by Gamal et al., who from Egyptian patients isolates of $K$. pneumoniae isolated IncR plasmids containing both bla $\mathrm{NDM}_{\mathrm{N}}$ and [34]. rmtF gene codes methyltransferase, which is responsible for modifying the aminoglycoside attachment site in
$16 \mathrm{~S}$ rRNA bacterial ribosome. This leads to bacterial resistance to this group of antibiotics [35]. Data from Yan et al. show that in isolates obtained in China multidrug resistant $K$. pneumoniae were present, which apart from the bla $\mathrm{NDM}_{\mathrm{N}}$ gene also had bla $\mathrm{KPC}_{\mathrm{K}-2}$ gene encoding carbapenemase belonging to class $A$ according to Ambler and enzyme group 2 according to Bush and Jacoby [14, 36, 37]. Ho et al. from Hong Kong isolated and sequenced the pNDM-HK plasmid. It belongs to the group of IncL/M plasmids. It was observed that beyond to the gene responsible for the mechanism of resistance associated with NDM carbapenemase $\left(b / a_{N D M-1}\right)$ it had other genes determining resistance to: $\beta$-lactams such as bla $a_{T E M-1}$ and bla $a_{D H A-1}$, aminoglycosides such as armA and aaaC2, macrolides such as mph2 and mel, and sulphonamides such as sul1 [38, 39].

\section{Types of NDM metallo- $\beta$-lactamases}

There are many different types of NDM metallo- $\beta$-lactamases, depending on their structure. The differences between them in the primary structure of the protein are minimal, and they are caused by point mutations resulting in the exchange of one amino acid for another. The main type of NDM enzyme is NDM-1. This form of carbapenemase was discovered in 2008 in a Swedish patient in New Delhi, India [23]. It has a mass of about $28 \mathrm{kDa}$ and is made of 269 amino acids [13]. Subsequent variants of this enzyme, marked sequentially from 2 to 17 , are very rare. NDM-3, $-4,-5,-6,-7,-8,-11,-12$, $-13,-15$, and -17 were detected in $E$. coli, while NDM-9, -10 , and -16 were detected in $K$. pneumoniae $[29,40]$. Importantly, NDM metallo- $\beta$-lactamases (especially 
NDM-1) are sometimes present in individual representatives of Vibrionaceae and other non-Enterobacteriaceae species [41].

\section{Carbapenemase-producing Enterobacteriaceae (CPE)}

The Enterobacteriaceae family, which have the ability to produce carbapenemases, are called CPE (Carbapenemase-Producing Enterobacteriaceae). According to the KORLD definition, in order to confirm their presence in a patient, it is necessary to either obtain a positive Carba NP test (Nordmann-Poirel), or to determine the production of carbapenemase in a KORLD facility, or to obtain the confirmation of carbapenemase presence using genetic tests. The study may include, for example, the patient's blood, an intraoperative segment taken from an infected wound, or bronchoscopy from a person diagnosed with pneumonia [42]. The mentioned Carba NP test is an extremely simple, cheap, and easy detection method, including bacilli from the Enterobacteriaceae family that produce carbapenemases [43]. For this group of bacteria, it has almost complete sensitivity and specificity compared to molecular methods [44]. This test involves the hydrolysis of imipenem by carbapenemases derived from the lysate of a suspension of bacteria derived from a biological sample. The $\mathrm{pH}$ of the solution decreases due to the acidity of antibiotic breakdown products, which causes the red colour in the alkaline phenol solution to change to yellow $[43,44]$.

\section{CPE in Poland in the years 2011 to 2016}

There is a very large reservoir of bacteria in Poland that can obtain the ability to produce carbapenemases. This is due to the widespread occurrence of both $E$. coli and $K$. pneumoniae representatives. In the years 2011 to 2016 , as much as $98.8 \%$ of all bacteria in which the NDM-1 enzyme was detected belonged to the species K. pneumoniae (Fig. 2). Approximately $1 \%$ of cases are representatives of the $E$. coli species. This means that every case of NDM+ strain in Poland is associated with the Enterobacteriaceae family [45]. In Poland, the first case of infection caused by a representative of the Enterobacteriaceae family producing New Delhi metallo- $\beta$-lactamase 1 (NDM) appeared in 2011 in the Mazowieckie region [46]. He was a middle-aged man transported by air to Warsaw from Congo, where he was admitted to hospital due to sudden cardiac arrest. In his urine, an $E$. coli bacterium was identified showing the presence of New Delhi metallo- $\beta$-lactamase 1. In spite of almost two weeks of colistin treatment, the patient

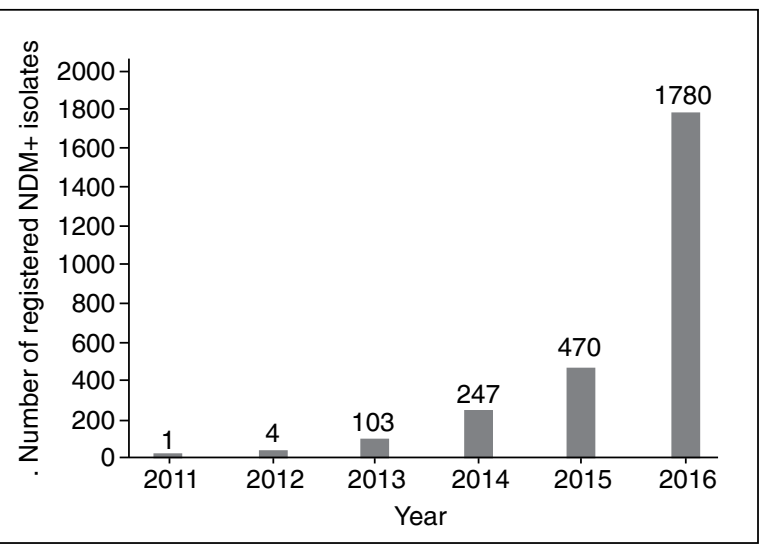

Figure 2. Number of registered cases of bacteria from the Enterobacteriaceae NDM-1 family from 2011 to 2016 [46, 49]

died due to multi-organ failure [47]. In the following year, four cases of infection with bacteria showing the presence of NDM enzymes were registered in the Wielkopolska region. A huge increase in the number of observed infection cases, equal to 103, took place in 2013. The number of infections in 2014 was more than twice as high as in the previous year, and since 2016 it has exceeded 1000 cases [46]. The KORLD data shows that, in the years between 2011 and 2016, 2605 cases of NDM+ isolates were recorded [45, 46]. According to data published by Baraniak et al., many cases of NDM+ from the Enterobacteriaceae family occurring in Poland, especially in the early years of their occurrence (2012-2014), were acquired abroad. For example, three cases of infection from 2013 were reported in patients from Montenegro, Afghanistan, and India. Due to the fact that the species showing the presence of the bla $a_{N D M-1}$ gene was $P$. mirabilis, the case of infection of a person returning from Afghanistan was particularly interesting [48].

The vast majority of cases, about $93.3 \%$, were identified in hospitals, hospices, and in the course of admitting patients to hospitals. Analysing the age of infected patients, it can be stated that about $65 \%$ of them were people over 65 years of age, and under the age of 19 years the cases of isolation of $\mathrm{NDM}+$ strains practically did not occur. Perhaps due to insufficient compliance with hygiene rules, observed more often in men than women, in the first mentioned group the number of infected was slightly higher [45]. From the data collected at the surgery department of the Medical University of Warsaw in 2012-2014 and published by Milner et al., it appears that from $236 \mathrm{~K}$. pneumoniae strains isolated from patients' biological materials 14 isolates (6\%) showed a mechanism of resistance to antibiotics associated with the NDM-1 enzyme. None of these isolates was 
obtained in 2012, while as many as 11 of them were from 2013. All NDM + was sensitive to gentamicin, but at the same time none of the isolates was sensitive to ertapenem. As many as $14 \%$ of isolates were not sensitive to colistin [3]. Nawfal Dagher et al. proved that registered in Lebanon, insensitive to colistin the $K$. pneumoniae isolate showed the presence of NDM-5 carbapenemase [50].

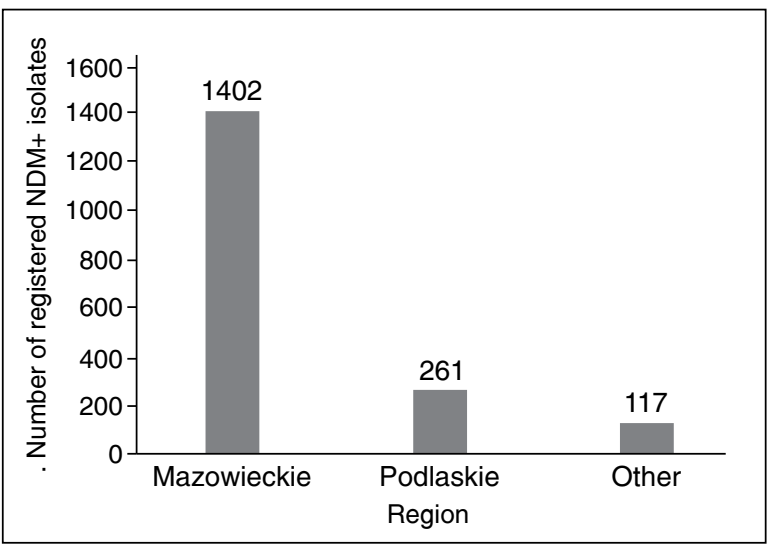

Figure 3. Number of registered cases of bacteria from the Enterobacteriaceae NDM-1 family in 2016 from the Mazowieckie and Podlaskie regions, relative to others [46]
1780 cases of Enterobacteriaceae NDM-1 bacteria were registered in 2016. About $78 \%$ of these cases took place in the Mazowieckie region (Fig. 3). In 14 regions (Fig. 4), the number of cases of bacteria containing the NDM-1 enzyme did not exceed 120, and it was more than two-fold lower than in the Podlaskie region. In the Podkarpackie, Opolskie, and Lubuskie regions no cases of NDM carbapenemase occurred in microorganisms [46].

\section{CPE in Poland in 2017}

Figures 5 and 6 show the numbers of recorded cases of bacteria from the Enterobacteriaceae NDM-1 family in the first three quarters registered in Mazowieckie, Podlaskie, and others (Fig. 5) and in regions outside Mazowieckie and Podlaskie (Fig. 6).

In 2017 about 2405 cases of NDM+ isolates were recorded - more than half were registered in the Mazowieckie region (Fig. 5) [46]. The Opolskie, Podkarpackie, and Lubuskie regions, similarly as in 2016, were the places of registration with the smallest number of $\mathrm{NDM}+$ strains. Both in the first and second quarter of 2017 , the number of registered cases of infection was higher than in the third quarter (Fig. 6) [51]. In the first quarter of 2017 the information about infection was

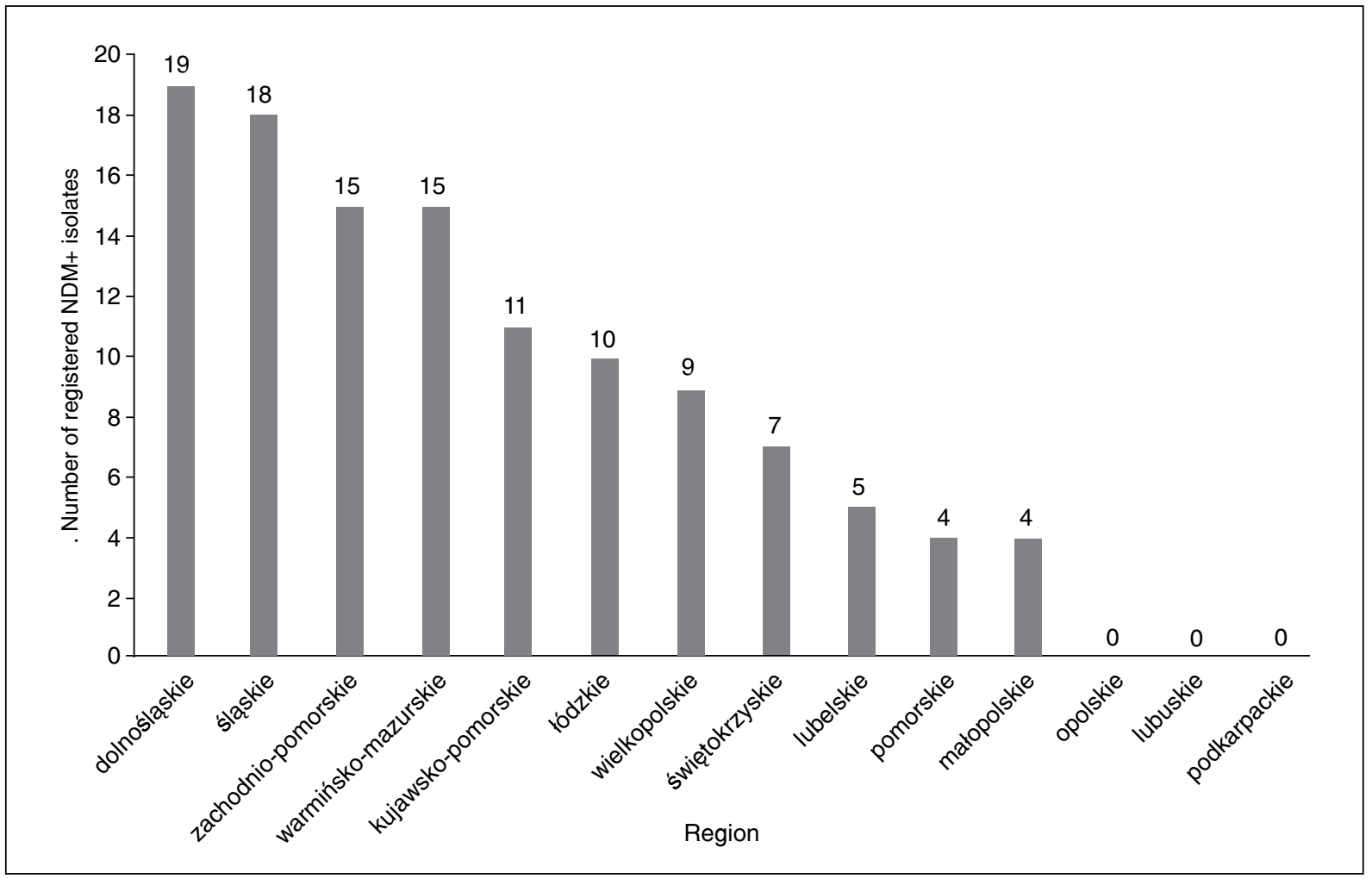

Figure 4. The number of recorded cases of bacteria from the Enterobacteriaceae NDM-1 family in 2016 [46] 
obtained as a result of screening tests more often than infection diagnosis [52]. All the data available for the Mazowieckie region, due to the very large number of

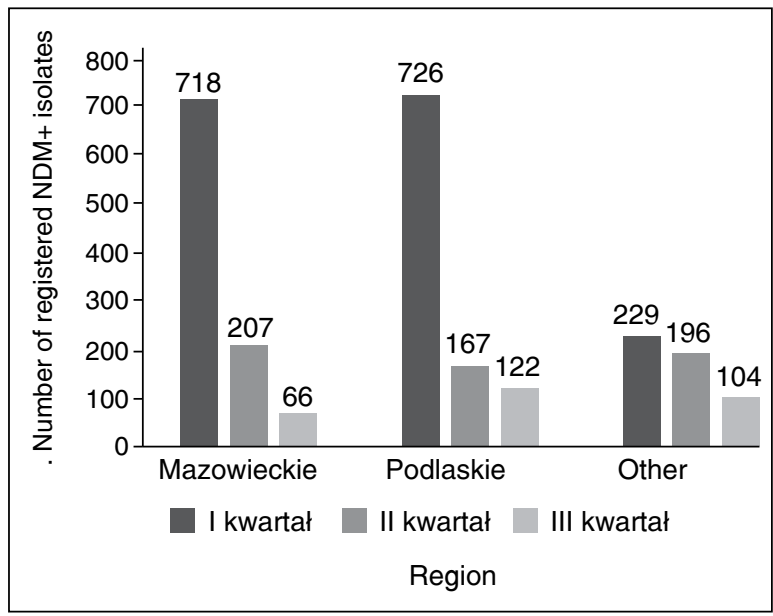

Figure 5. Number of recorded cases of bacteria from the Enterobacteriaceae NDM-1 family in the first three quarters of 2017 in the Mazowieckie and Podlaskie regions, relative to others [51] samples, from the period after the second quarter of 2017 can be considered undervalued, due to restrictions concerning the confirmation of the presence of carbapenemases in some $K$. pneumoniae strains producing metallo- $\beta$-lactamases [46, 51].

Another interesting KORLD report allows for a more accurate analysis of data on the number of NDM+ isolates from 2016 and 2017. In the first quarter of 2017, more cases of patients with Enterobacteriaceae, mainly K. pneumoniae, NDM + were recorded than in the first quarter of 2016 (about 150\%), particularly in the Mazowieckie and Podlaskie regions. In the first of them, in both years, a carrying of bacteria than infection was observed in twice as many people. On the other hand, in the Podlaskie region in the first quarter of 2016 the number of patients infected and those who were carriers of bacteria was similar, and in the first quarter of 2017 the number of carriers became almost twice as high as those infected [52].

\section{CPE in Poland after 2017}

In 2018, probably due to the change in the procedures for obtaining and registering test results by

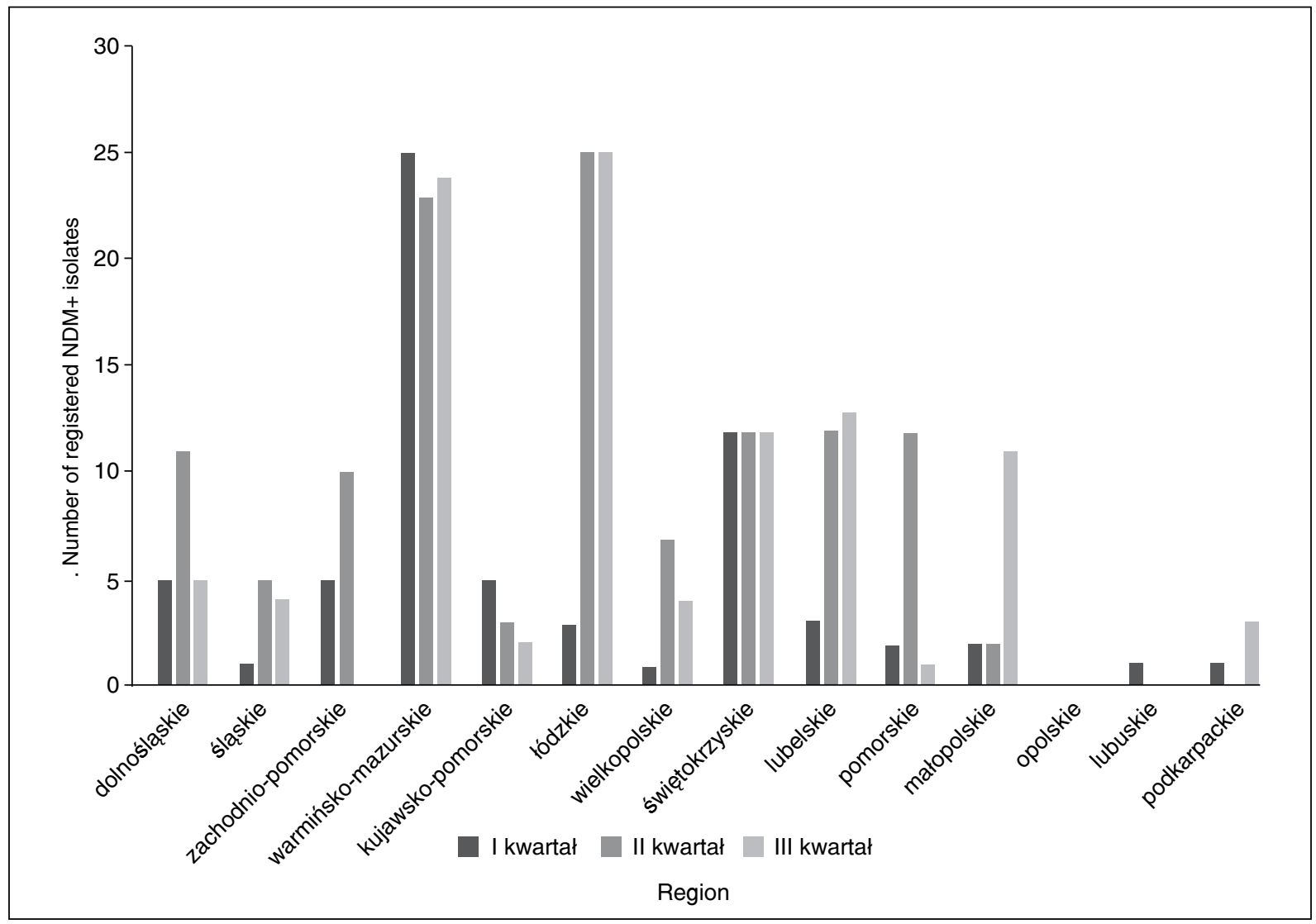

Figure 6. Number of recorded cases of bacteria from the Enterobacteriaceae NDM-1 family in the first three quarters registered in regions outside Mazowieckie and Podlaskie [51] 
Table 1. Summary of the numbers of reported occurrences of NDM+ isolates in 2016-2018 from Podlaskie, Śląskie, Wielkopolskie, and Zachodniopomorskie regions

\begin{tabular}{lccc}
\hline Region & $\mathbf{2 0 1 6}$ & $\mathbf{2 0 1 7}$ & $\mathbf{2 0 1 8}$ \\
\hline Podlaskie & 261 & 675 & 786 \\
Śląskie & 18 & 12 & 53 \\
Wielkopolskie & 9 & 20 & 35 \\
Zachodniopomorskie & 15 & 16 & 31 \\
\hline
\end{tabular}

KORLD in the Mazowieckie region, the number of registered NDM-1 isolates was lower than in 2017 and equalled 2355 [46]. However, this does not mean a decrease in the risk of bacteria from the Enterobacteriaceae family that produce NDM-1 carbapenemase. Not counting the Mazowieckie region, the number of registered NDM+ isolates in 2016-2018 increases in almost every region [46]. Table 1 presents a summary of the numbers of reported occurrences of NDM + isolates from the four selected Polish regions.

The data from the Region Sanitary and Epidemiological Station in Warsaw show that 23 outbreaks of nosocomial infections were reported in 2018, which were caused by $K$. pneumoniae with the ability to form metallo- $\beta$-lactamase. From these 23 outbreaks, seven recognized by KORLD were caused by bacteria-producing enzymes NDM-1. Apart from these cases, 51 transmissions of $K$. pneumoniae MBL-type colonisation took place [53].

\section{Summary and conclusions}

Bacteria belonging to the Enterobacteriaceae family, having the bla ${ }_{N D M}$ gene in their genome, are a growing problem not only in Poland but also throughout the world. The spread of multiresistant strains whose genes determining antibiotic resistance are located on plasmids is particularly worrying. Therefore, it is necessary to constantly try to discover new substances that inhibit or eliminate the effects of carbapenemases, such as their inhibitors, and new substances with bactericidal activity. In stopping the spread of antibiotic-resistant faecal sticks, hygiene, frequent hand washing, strict compliance with sanitary standards, and the responsibility of all who have contact with antibiotics are extremely important.

\section{References}

1. Murray PR, Rosenthal KS, Pfaller MA. Mikrobiologia. Elsevier Urban \& Partner, Wroclaw, 2011, s. 195-199. : 293-307.

2. Jabłoński L. Podstawy mikrobiologii lekarskiej: podręcznik dla studentów. Państwowy Zakład Wydawnictw Lekarskich, Warszawa, 1979, s. 265-269.
3. Milner A, et al. Analiza czestości wystepowania i ocena lekowrażliwości szczepów Klebsiella pneumoniae NDM-1 na oddziale chirurgii CSK WUM w okresie 1.01.2012-30.09.2014 roku Postępy Nauk Medycznych, 2015; XXVIII(4): 261-268.

4. Schlegel HG. Mikrobiologia ogólna. Wydawnictwo Naukowe PWN, Warszawa 2003, s 31-35. ; 140: 419-428.

5. Popowska M. Antybiotykooporność w środowisku naturalnym - przyczyny i konsekwencje. Kosmos. 2017; 66(1): 81-91.

6. Olszanecki R, Wołkow P, Jawień J. Farmakologia. Redakcja naukowa Ryszard Korbut. Wydawnictwo Lekarskie PZWL, Warszawa 2017, s. : 233-244.

7. Janiec W, et al. Krupińska. Farmakologia Podręcznik dla studentów farmacji. Wydanie V unowocześnione. Wydawnictwo Lekarskie PZWL, Warszawa, 2005, s. : 927-955.

8. Livermore DM. beta-Lactamases in laboratory and clinical resistance. Clin Microbiol Rev. 1995; 8(4): 557-584, indexed in Pubmed: 8665470

9. Nikonorow E, Baraniak A, Gniadkowski M. Oporność bakterii z rodziny Enterobacteriaceae na antybiotyki $\beta$-laktamowe wynikająca z wytwarzania $\beta$-laktamaz. Post Mikrobiol. 2013; 52(3): 261-271.

10. Cahill ST, Cain R, Wang DY, et al. Cyclic Boronates Inhibit All Classes of $\beta$-Lactamases. Antimicrob Agents Chemother. 2017; 61(4), doi: 10.1128/AAC.02260-16, indexed in Pubmed: 28115348.

11. Ambler RP, Coulson AF, Frère JM, et al. A standard numbering scheme for the class A beta-lactamases. Biochem J. 1991; 276 ( Pt 1): 269-270, doi: 10.1042/bj2760269, indexed in Pubmed: 2039479.

12. Rolain JM, Parola P, Cornaglia G. New Delhi metallo-beta-lactamase (NDM-1): towards a new pandemia? Clin Microbiol Infect. 2010; 16(12): 1699-1701, doi: 10.1111/j.1469-0691.2010.03385.x, indexed in Pubmed: 20874758.

13. Leis K, Mazur E, Szyoerski P, et al. Metallo-beta-lactamases: NDM Journal of Education, Health and Sport. 2019; 9(6): 27-40.

14. Bush K, Jacoby GA, Medeiros AA. A functional classification scheme for beta-lactamases and its correlation with molecular structure. Antimicrob Agents Chemother. 1995; 39(6): 1211-1233, doi: 10.1128/aac.39.6.1211, indexed in Pubmed: 7574506.

15. Deshpande P, Rodrigues C, Shetty A, et al. New Delhi Metallo-beta lactamase (NDM-1) in Enterobacteriaceae: treatment options with carbapenems compromised. J Assoc Physicians India. 2010; 58: 147-149, indexed in Pubmed: 20848811.

16. Tooke $\mathrm{CL}$, Hinchliffe $\mathrm{P}, \mathrm{Bragginton} \mathrm{EC}$, et al. $\beta$-Lactamases and $\beta$-Lactamase Inhibitors in the 21st Century. J Mol Biol. 2019; 431(18): 3472-3500, doi: 10.1016/j.jmb.2019.04.002, indexed in Pubmed: 30959050.

17. McGeary RP, Tan DTc, Schenk G. Progress toward inhibitors of metallo- $\beta$-lactamases. Future Med Chem. 2017; 9(7): 673-691, doi: 10.4155/fmc-2017-0007, indexed in Pubmed: 28504895.

18. Christopeit T, Leiros HKS. Fragment-based discovery of inhibitor scaffolds targeting the metallo- $\beta$-lactamases NDM-1 and VIM-2. Bioorg Med Chem Lett. 2016; 26(8): 1973-1977, doi: 10.1016/j. bmcl.2016.03.004, indexed in Pubmed: 26976213

19. King AM, Reid-Yu SA, Wang W, et al. Aspergillomarasmine A overcomes metallo- $\beta$-lactamase antibiotic resistance. Nature. 2014; 510(7506): 503-506, doi: 10.1038/nature13445, indexed in Pubmed: 24965651.

20. González MM, Kosmopoulou M, Mojica MF, et al. Bisthiazolidines: A Substrate-Mimicking Scaffold as an Inhibitor of the NDM-1 Carbapenemase. ACS Infect Dis. 2015; 1(11): 544-554, doi: 10.1021/acsinfecdis.5b00046, indexed in Pubmed: 27623409.

21. Ojdana D, Gutowska A, Sacha P, et al. Activity of Ceftazidime-Avibactam Alone and in Combination with Ertapenem, Fosfomycin, and Tigecycline Against Carbapenemase-Producing . Microb Drug Resist. 2019; 25(9): 1357-1364, doi: 10.1089/mdr.2018.0234, indexed in Pubmed: 31295055.

22. Żabicka D. Monitorowanie oporności w Polsce - dane sieci EARS-Net Zakład Epidemiologii i Mikrobiologii Klinicznej; Krajowy Ośrodek Referencyjny ds. Lekowrażliwości Drobnoustrojów, Narodowy Instytut 
Leków, Warszawa 2016, http://www. korld edu pl/pdf/Monitorowanie_dane_2016_strona_KORLD pdf (31 08. ; 2019.

23. Yong D, Toleman MA, Giske CG, et al. Characterization of a new metallo-beta-lactamase gene, bla(NDM-1), and a novel erythromycin esterase gene carried on a unique genetic structure in Klebsiella pneumoniae sequence type 14 from India. Antimicrob Agents Chemother 2009; 53(12): 5046-5054, doi: 10.1128/AAC.00774-09, indexed in Pubmed: 19770275.

24. Cai $\mathrm{Y}$, Chen $\mathrm{C}$, Zhao $\mathrm{M}$, et al. High Prevalence of Metallo- $\beta$-Lactamase-Producing Enterobacter cloacae From Three Tertiary Hospitals in China. Frontiers in Microbiology. 2019; 10, doi 10.3389/fmicb.2019.01610

25. Bocanegra-lbarias P, Garza-González E, Morfín-Otero R, et al. Molecular and microbiological report of a hospital outbreak of NDM-1-carrying Enterobacteriaceae in Mexico. PLoS One. 2017; 12(6): e0179651, doi 10.1371/journal.pone.0179651, indexed in Pubmed: 28636666.

26. Khan AU, Nordmann P. NDM-1-producing Enterobacter cloacae and Klebsiella pneumoniae from diabetic foot ulcers in India. J Med Microbiol. 2012; 61 (Pt 3): 454-456, doi: 10.1099/jmm.0.039008-0, indexed in Pubmed: 22034164.

27. Kumarasamy KK, Toleman MA, Walsh TR, et al. Emergence of a new antibiotic resistance mechanism in India, Pakistan, and the UK: a molecular, biological, and epidemiological study. Lancet Infect Dis. 2010 10(9): 597-602, doi: 10.1016/S1473-3099(10)70143-2, indexed in Pubmed: 20705517

28. Karczewski M, Tomczak H, Piechocka-Idasiak I, et al. Is multiresistan Klebsiella pneumoniae New Delhi metallo-beta-lactamase (NDM-1) a new threat for kidney transplant recipients? Transplant Proc. 2014 46(7): 2409-2410, doi: 10.1016/j.transproceed.2014.06.050, indexed in Pubmed: 25242796.

29. Grover SS, Doda A, Gupta N, et al. New Delhi metallo- $\beta$-lactamase - type carbapenemases producing isolates from hospitalized patients: A pilot study. Indian J Med Res. 2017; 146(1): 105-110, doi: 10.4103/ijmr.IJMR 594 15, indexed in Pubmed: 29168466.

30. Poirel L, Dortet L, Bernabeu S, et al. Genetic features of blaNDM-1-positive Enterobacteriaceae. Antimicrob Agents Chemother. 2011 55(11): 5403-5407, doi: 10.1128/AAC.00585-11, indexed in Pubmed: 21859933

31. Poirel L, Hombrouck-Alet C, Freneaux C, et al. Global spread of New Delhi metallo- $\beta$-lactamase 1. Lancet Infect Dis. 2010; 10(12): 832, doi: 10.1016/S1473-3099(10)70279-6, indexed in Pubmed: 21109172.

32. Poirel L, Schrenzel J, Cherkaoui A, et al. Molecular analysis of NDM-1-producing enterobacterial isolates from Geneva, Switzerland. J Antimicrob Chemother. 2011; 66(8): 1730-1733, doi: 10.1093/jac/dkr174, indexed in Pubmed: 21628303.

33. Poirel L, Al Maskari Z, Al Rashdi F, et al. NDM-1-producing Klebsiella pneumoniae isolated in the Sultanate of Oman. J Antimicrob Chemother. 2011; 66(2): 304-306, doi: 10.1093/jac/dkq428, indexed in Pubmed: 21098539

34. Gamal D, Fernández-Martínez M, Salem D, et al. Carbapenem-resistan Klebsiella pneumoniae isolates from Egypt containing blaNDM-1 on IncR plasmids and its association with rmtF. Int J Infect Dis. 2016; 43 17-20, doi: 10.1016/j.ijid.2015.12.003, indexed in Pubmed: 26686939

35. Galimand M, Courvalin P, Lambert T. RmtF, a new member of the aminoglycoside resistance 16S rRNA N7 G1405 methyltransferase family. Antimicrob Agents Chemother. 2012; 56(7): 3960-3962, doi 10.1128/AAC.00660-12, indexed in Pubmed: 22547620.

36. Wang D, Hou W, Chen J, et al. Characterization of the blaKPC-2 and blaKPC-3 genes and the novel blaKPC-15 gene in Klebsiella pneumoniae. J Med Microbiol. 2014; 63(Pt 7): 981-987, doi 10.1099/jmm.0.073841-0, indexed in Pubmed: 24713357.

37. Yan J, Pu S, Jia X, et al. Multidrug Resistance Mechanisms of Carbapenem Resistant Klebsiella pneumoniae Strains Isolated in Chongqing, China. Ann Lab Med. 2017; 37(5): 398-407, doi 10.3343/alm.2017.37.5.398, indexed in Pubmed: 28643488

38. Ho PL, Shek RH, Chow KH, et al. Detection and characterization of extended-spectrum beta-lactamases among bloodstream isolates of Enterobacter spp. in Hong Kong, 2000-2002. J Antimicrob Chemother 2005; 55(3): 326-332, doi: 10.1093/jac/dki010
39. Ho PL, Shek RH, Chow KH, et al. Detection and characterization of extended-spectrum beta-lactamases among bloodstream isolates of Enterobacter spp. in Hong Kong, 2000-2002. J Antimicrob Chemother. 2005; 55(3): 326-332, doi: 10.1093/jac/dki010.

40. Khan AU, Maryam L, Zarrilli R Structure Genetics and Worldwide Spread of New Delhi Metallo- $\beta$-lactamase (NDM): a threat to public health. BMC Microbiol. 2017; 17(1): 101, doi: 10.1186/s12866-0171012-8, indexed in Pubmed: 28449650

41. Nordmann P, Poirel L, Walsh TR, et al. The emerging NDM carbapenemases. Trends Microbiol. 2011; 19(12): 588-595, doi: 10.1016/j. tim.2011.09.005, indexed in Pubmed: 22078325.

42. Narodowy Program Ochrony Antybiotyków: PAŁECZKI JELITOWE ENTEROBACTERIACEAE WYTWARZAJĄCE KARBAPENEMAZY (CPE) http://antybiotyki. edu pl/wp-content/uploads/dokumenty/Definicja-przypadku-CPE pdf (31 08. ; 2019

43. Literacka E, Żabicka D, Gniadkowski M, et al. Test Carba NP i CarbAcineto - szybkie testy do wykrywania nabytych karbapenemaz u pałeczek Enterobacteriaceae, Pseudomonas spp oraz Acinetobacter spp Rekomendacje 2015, http://www korld edu pl/pdf/TestCarbaNPrekomendacje2015 pdf (31 08. ; 2019

44. Nordmann P, Poirel L, Dortet L. Rapid detection of carbapenemase-producing Enterobacteriaceae. Emerg Infect Dis. 2012: 18(9): 1503-1507, doi: 10.3201/eid1809.120355, indexed in Pubmed: 22932472

45. Krajowy Ośrodek Referencyjny ds. Lekowrażliwości Drobnoustrojów: Pałeczki jelitowe Enterobacteriaceae wytwarzajace karbapenemazy (CPE) w Polsce - sytuacja w 2016. http://www.korld.edu.pl/pdf/CPEraport2016.pdf (31.08.2019)

46. Literacka E, Żabicka D, Hryniewicz W, et al. RAPORT KORLD Dane Krajowego Ośrodka Referencyjnego ds. Lekowrażliwości Drobnoustrojów (KORLD), dotyczące pałeczek Enterobacterales wytwarzających karbapenemazy NDM, KPC, VIM i OXA-48 na terenie Polski w latach 2006 -2018. http://korld.edu.pl/pdf/Raport\%20KORLD\%202019 EL 2. pdf (31.08.2019).

47. Fiett J, Baraniak A, Izdebski $\mathrm{R}$, et al. The first NDM metallo- $\beta$-lactamase-producing Enterobacteriaceae isolate in Poland: evolution of IncFll-type plasmids carrying the bla(NDM-1) gene. Antimicrob Agents Chemother. 2014; 58(2): 1203-1207, doi: 10.1128/AAC.01197-13, indexed in Pubmed: 24247128.

48. BaraniakA, Izdebski R, Fiett J, et al. NDM-producing Enterobacteriaceae in Poland, 2012-14: inter-regional outbreak of Klebsiella pneumoniae ST11 and sporadic cases. J Antimicrob Chemother. 2016; 71(1): 85-91, doi: 10.1093/jac/dkv282, indexed in Pubmed: 26386745

49. Baraniak A, Machulska M, Żabicka D, et al. NDM-PL Study Group Towards endemicity: large-scale expansion of the NDM-1-producing Klebsiella pneumoniae ST11 lineage in Poland, 2015-16. J Antimicrob Chemother. 2019; 74(11): 3199-3204, doi: 10.1093/jac/dkz315, indexed in Pubmed: 31406993

50. Nawfal Dagher T, Azar E Al-Bayssari C et al First Detection of Colistin-Resistant in Association with Carbapenemase Isolated from Clinical Lebanese Patients. Microb Drug Resist. 2019; 25(6): 925-930, doi: 10.1089/mdr.2018.0383, indexed in Pubmed: 30883263

51. Żabicka D, Literacka E, Gniadkowski M, et al. Raport Krajowego Ośrodka Referencyjnego ds. Lekowrażliwości Drobnoustrojów Występowanie Enterobacteriaceae (głównie Klebsiella pneumoniae) wytwarzających karbapenemaze New Delhi (NDM) na terenie Polski w okresie I - III kwartał 2017 roku. http://www.korld.edu.pl/pdf/Raport_NDM_18-122017_strona.pdf (31.08.2019)

52. Żabicka D, Gniadkowski M, Ozorowski T, et al. Raport Krajowego Ośrodka Referencyjnego ds. Lekowrażliwości Drobnoustrojów Występowanie Enterobacteriaceae (Klebsiella pneumoniae) wytwarzających karbapenemazy typu New Delhi na terenie Polski w I kwartale 2017 roku Strategia regionalna kontroli rozprzestrzeniania Enterobacteriaceae wytwarzających karbapenemazy (ang. CPE- Carbapenemase-Producing Enterobacteriaceae), 15. 06 2017, http://korld edu pl/pdf/NDM_Raport_ I kwartal_2017-05-07-1 pdf (31 08. ; 2019.

53. Wojewódzka Stacja Sanitarno-Epidemiologiczna w Warszawie: Stan Sanitarny województwa mazowieckiego 2018, 03. 2019. http:// wsse.waw.pl/files/wsse/pliki WSSE/Organizacyjny 2019/Stan sanitarny_woj.mazowieckiego_2018r.pdf (31.08.2019) 